\title{
Traditional Mask Innovation in Learning Art in Higher Education in the Era of the Industrial Revolution 4.0
}

\author{
Martono
}

Yogyakarta State University, Yogyakarta, Indonesia

Email:martono@uny.ac.id

\begin{abstract}
Innovation is an effort to develop new products using the basic idea of traditional art developed in the community through learning art in higher education. The development of learning to make creative masks involves the aspects of preservation and development to make good quality products. This research employs a qualitative descriptive approach. The data were collected from interviews, observations, and documentation. They were then analyzed using descriptive analysis to measure innovation in learning outcomes. The results showed that (1) the sources of learning ideas were based on the materials of traditional mask art developed in the community, (2) the development of mask for new creations and souvenirs have the aspects of memory; practicality, simplicity, and aesthetic.
\end{abstract}

Keywords: innovation, mask, art learning

\section{INTRODUCTION}

The $21^{\text {st }}$ century arts education has to be based on the culture of the nation that carries some social values. For example, families and schools can be the center of local and national cultural development. Schools as one of the cultural developers have not involve the intellectual aspects in depth. They are still progressing to go to that direction, although the impacts remain unclear. Even though the aspects of creation and innovation become the main emphasis on the development of industry 4.0, the aspect of personality is greatly important as the identity of Indonesians' characters. This can be seen through the efforts done by the government to implement the local wisdom and national characters on some certain subjects through various aspects. When some national issues arises and are shown in the mass media describing the fading of the character of the nation, some heated discussions can be seen everywhere, like in the seminars or at schools. It is not too late to be more aware and wake up from a dream to preserve our national culture as a national identity. One of the ways to do this is by teaching art to strengthen the nation's character.

Culture is related to the symbol system, which is used as a reference and guideline for people's lives. This meaning is transmitted [7] through symbolic codes. This understanding of culture means that culture is an expression of society in the form of ideas and human behavior in the community. The culture in our society is so strong. Our poets and masters are so powerful in making symbols in their cultural art. As a big and multicultural nation that has a wide variety of cultural treasures, it is important to preserve and develop those in order to maintain their existence as our personality and culture. As stated by Ida Bagus Gede, a symbol explains the dual function of transcendent-vertical (relating to the reference, size, pattern of society's behavior) and horizontal immanence as a means of communication based on the context and solidarity relations between the supporters [2].

The existence of traditional art such as masks will inevitably be replaced by the new culture, so it is essential to create new ideas to maintain and develop the art through learning at schools and higher education. As a reflection and innovation in the future, Higher Education Institutions such as Yogyakarta State University has developed art innovations to educate, preserve and develop traditional and modern mask art through craft making on campus. The field of education has the responsibility to preserve and develop the nation's culture through arts education with cultural insights. There are indeed many cultural phenomena focused on the romanticism of past cultures that have failed to respond to the contemporary developments or to contextualize cultural values in response to the current changes. Human as social and cultural creatures must be cultured. As said by Tilaar, a person has to master the culture and behaves in accordance with cultural values, especially ethical and moral values that live in the culture [8]. All of that must be pursued and learned together through art learning so that people have an appreciation and concern for the art. 
However, when dealing and mingling with a large community called nation, the influence of global communication and the values of social solidarity are narrowed down to a form of privatization. This leads to a more individual style of art that carry a personal expression that is more expressive and creative. The development of space and time causes the history of art to always be in a dynamic and dialectical state. Dynamic means it is always changing and developing in line with human development from time to time. The emergence of a new work such as batik masks and souvenir masks in various sizes is a new form of breakthrough inspired by previous art works. In the meantime, those new art works that are claimed to be innovative will become myths until there are other newer and more innovative works. Thus dialectics runs continuously in the historical spectrum of art development. The representation of space and time in the art that can explicitly show that prehistoric art is animist art. That is caused by the phenomenon of society that has a belief in ancestral spirits and supernatural powers. The meetings with Indians lead to the creation of classical works of art such as reliefs, puppets, sculptures, masks, batik, the meetings with the Arabians lead to the creation decorative art and calligraphy, while the meetings with Chinese and Japanese lead to the creation ceramic art, and so on.

Art teachers, artists, and other art workers carry out the education process not only by transforming cultural values, but also by creating, changing, renewing, and enriching the treasures of art and culture. Modernism is poured hegemonistically through various infrastructure and superstructure institutions that exist in societies outside the west. One of the ways to do this modernism that is considered to be the most effective is education [3]. However, the present millennial generation is less interested in learning traditional art, and they prefer to study popular art. Those who learn traditional art through formal and informal educational institutions are young generation from other countries instead. As a result, our traditional culture starts to grow and well flourish in foreign countries. It is ironic that Indonesian generation, as the owners of indigenous cultures, are less concerned about developing and preserving their own culture. However, they could easily get irritated when the culture is developed and used by other countries. The case should be a reminder for us, the Indonesian, to preserve and develop our culture.

\section{MASKS LEARNING IN HIGHER EDUCATION}

Feynman is a Nobel winner from America who doubted the ability of traditional mathematics to describe the new world that was most used at that time [5]. Many people used this traditional mathematics to describe the new world but it did not work. However, he realized that if we had no doubts, we would not be able to have new innovative ideas according to the development of the time. Doubt is the key to opening new ideas. Nothing in this world is truly certain, nor is the existence of traditional art such as classical masks that were once a trusted, favored, owned art that has gradually shifted by the modern culture. As the descendents and developers of culture that have doubts, we have to have hopes to preserve masks and to have innovative thinking to maintain and develop new designs.

The preservation and development of culture needs to be done through education to make the dreams and hopes come true. The learning process starts from having doubt, being curious, and exploring in various ways. The process of learning art can be done through the process of socialization and enculturation. Socialization is a term that is often used by sociologists or other social scientist to provide an understanding of the process of transferring knowledge, ideas, attitudes, and behavior from one generation to generation. The process of socialization as an educational process can be started from family, playmates, formal education, non-formal education, and community relations. The anthropologists call this process as the enculturation process, while the inspiration of the process is to form knowledge and behavior so that children are able to be independently named the internalization process. The process of understanding traditional art can be done through an exploration process in various ways.

Enculturation is a process of civilization, socialization is a social process, and internalization is a process of crystallization in a person. These can be seen in art education, such as art, literature, dance, music, in the form of appreciation and creative expression. The development of creativity needs to be fostered as early as possible in order to shape civilized humans. To strengthen the process of art learning, Goldberg describes art which is integrated in the teaching process: learning about art, learning with art, and learning through art [4]. Therefore, the internalization process is personal that is needed for each individual to form his/her identity. This is determined by the boundaries or opportunities of the socio-cultural conditions of the local community. In addition, the internalization process can be done through culture education of $\mathrm{K} \mathrm{H}$ Dewantoro, i.e. education that enhances human values p. 324 [6]. Art education must be about preserving and developing the cultural traditions through classroom learning. Indonesia is considered as superior in traditional art and culture, and this should be maintained through curriculum and learning art at schools. Cultural development that also contains the development of creative industries need to consider the potential of existing art. This can be done through, first, identifying and mapping national wisdom to obtain a real picture of the nation's cultural wealth as a source of future development, and second, constructing the nation's wisdom to tackle the challenges of global development.

Creative educators who have futuristic thinking usually dare to make good decisions for the learning process. Those who want to develop their expertise must develop and strengthen their professions and competencies. In the 
context of learning art in higher education, we can use a variety of learning approaches developed by the Ministry of Education in competency-based curriculum such as contextual learning, innovative learning, project-based learning and so on. Joice and Weil said that different learning objectives require different approaches, different learning activities, different materials, and different roles of teachers and students [1]. The most useful formulation of learning objectives is a formula showing the behavior that students will learn. The Innovation learning uses the $3 \mathrm{~N}$ learning concept of Ki Hadjar Dewantoro which includes Niteni, Nirokake, Nambahi, that means observing, understanding, imitating, and modifying in developing creative industries, and the spirit of learning that is carried out using apprenticeship system in informal arts education as is done by the masters and craftsmen. The development of the learning model that comes from long experience in accordance with the text, the context and contextualization of learning will be more meaningful than using existing approaches if it is regarded to be inappropriate. The development of the learning model could adapt the spirit of the nation's own culture packaged in multimethod, multimedia, and multimodel and be based on the nation's cultural values .

The innovation of traditional mask can be done through the process of imagination and interpretation of the existing masks in accordance with the current trend. Creativity and innovation are both needed by lecturers in higher education. Learning science must be performed like scientists to get reliable scientific findings. Studying art must be performed like artists to produce aesthetic and meaningful art. Art requires creative mind in order to make good quality art. Making art is like writing a story to produce a good quality story. Reading Panji Mask can be innovated into a new form of mask to add aesthetic treasures and new functions. Innovative thinking means thinking to create new things. Innovations are needed to add to the diversity of the existing designs. The following is one of the innovative methods of classical Panji masks as an innovative masks finished with acrylic and batik techniques.
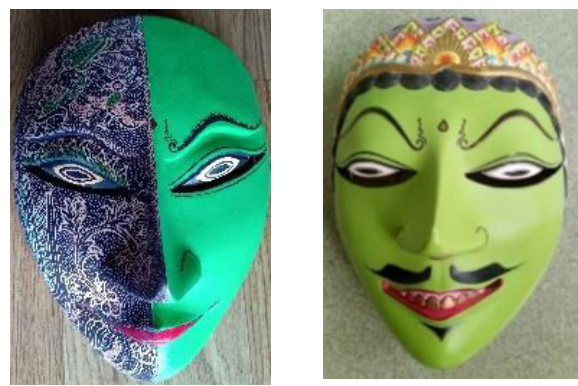

Fig. 1. Traditional Panji mask (left) and innovative Panji mask (right)

Competencies of educators teaching arts in higher education need to be continuously developed to motivate and facilitate students to explore and find new innovations.
When learning about mask art, students are taught to make classical masks by imitation with the hope that they can learn the skills, perseverance, discipline, and accuracy of their forms, aesthetics, and functional values. Traditional masks are made to have symbolic meaning through the form of visual symbols. If the making is not based on the standard, they will lose the aesthetic and philosophical values of the characters. Besides, the making has also consider the ergonomics values, as they are made to be used for shows so they must be comfortable and safe to wear. Therefore, learning about traditional masks also means learning to be skillful, meticulous, thorough, and disciplined.

However, the case with learning about mask innovation or creation developed from traditional masks is different. This process aims to recognize and preserve traditional art in order to develop students' creativity in creating new designs from the existing designs. The ultimate goal of this process is to build student awareness that Indonesia has a wide variety of culture and it has to be preserved, developed, and loved. Students are taught how to appreciate traditional art and are also guided in making the innovation of new art forms that can be accepted by the community. In the current industrial era 4.0, art learning needs to use modern technology in creating innovations. For example, creating new designs of innovation masks that can move, glow and make sound, and finding a form of robotic work that carries the cultural values. Traditional masks will then expand in terms of their form, aesthetic values, and functions.

\section{CONCLUSION}

Indonesian culture was formed and born by our ancestors as a great work that has meaning and function as a symbol of the cultural civilization of its community. Innovation starts with doubt, because doubt is the key to opening new ideas. The innovation of new masks cannot be separated from the existence of current and previous mask works. Therefore, the previous works are inspiration for the current and future creators added with different foundation and concept according to the era. Learning innovative art from traditional culture needs to be done to strengthen the existence of traditional art and to develop creation to deal with the future development.

Learning about masks must be able to provide a learning experience for students who truly experience the process of appreciating the expression of art in a contextual and actual manner. The learning is carried out using the $3 \mathrm{~N}$ method (Niteni, Nirokake, Nambahi) so that students have an insight of appreciation and creativity to master art skills. Life skills-oriented arts education has to be developed based on the industrial revolution 4.0 so that students have the provision to face the daily life problems in the society. Learning about art, learning with art, and learning through mask innovation can be done by choosing a type of traditional local mask and modifying it into a new creation that is developed in accordance with the development and needs of the surrounding community. 
This type of $\mathrm{rt}$ education with a contextual approach is aimed at making the learning process at school identical with what culture developed in the community. The important thing that educators must do is facilitating and motivating students so that their art competences can develop properly.

\section{REFERENCES}

[1] Anderson, Lorin W., and David R. Krathwohl. "A revision of Bloom's taxonomy of educational objectives." A Taxonomy for Learning, Teaching and Assessing. Longman, New York (2001).

[2] Dharsono, Sony Kartika. "Budaya Nusantara, Kajian Konsep Mandala, dan Konsep Tri-Loka terhadap Pohon Hayat pada Batik Klasik." Bandung: Rekayasa Sains (2007).

[3] Djatiprambudi, Djuli.Tinjauan Seni. Program semiQue IV Dikti Depdiknas (2003).

[4] Goldberg, Merryl Ruth. Arts and learning: An integrated approach to teaching and learning in multicultural and multilingual settings. Addison Wesley Publishing Company, 1997.

[5] Judkins, Rod. The art of creative thinking. Hachette UK, 2015.

[6] Dewantara, Ki Hadjar. "Pemikiran, Konsepsi, Keteladanan, Sikap Merdeka." Yogyakarta: Majelis Luhur Persatuan Taman Siswa (2013).

[7] Rohidi, Tjetjep Rohendi. Kesenian dalam pendekatan kebudayaan. STISI Press, 2000.

[8] Tilaar, Henry Alexis Rudolf, and Mukhlis. Pendidikan, kebudayaan, dan masyarakat madani Indonesia. Remaja Rosdakarya, 1999. 